\title{
Gonadotrophin release in untreated congenital virilising adrenal hyperplasia
}

\author{
A. PERTZELAN, Z. LARON,* M. ADLER-BIER, R. PRAGER-LEWIN, AND \\ H. KAUFMAN
}

From the Institute of Paediatric and Adolescent Endocrinology, Steroid Hormone Laboratory, Beilinson Medical Centre, Petah Tikva, Sackler School of Medicine, Tel Aviv University, Israel

SUMMARY A 9.9-year-old boy and a 9.8-year-old girl with virilising congenital adrenal hyperplasia were subjected to an IV LH-RH (luteinising hormone-releasing hormone) test $\left(50 \mu \mathrm{g} / \mathrm{m}^{2}\right)$ before initiation of therapy with corticosteroids. The pattern of response of LH and follicle-stimulating hormone to LH-RH was found to correspond to the stage of their precocious sexual development and advanced bone age, but not to their chronological age. This finding has implications with regard to the mechanism controlling gonadotrophin secretion at puberty.

The regulation of gonadotrophin secretion in untreated patients with congenital adrenal hyperplasia (CAH) has been a matter of controversy. Stevens and Goldzieher (1968) measuring urinary gonadotrophins found raised luteinising hormone (LH) and follicle-stimulating hormone (FSH) in untreated subjects with CAH. Klingensmith et al. (1976), in contrast, found that the development of normal puberty is suppressed until initiation of therapy. Recently the clinical use of luteinising hormonereleasing hormone (LH-RH) has made possible a re-evaluation of this problem (Reiter et al., 1975; Wentz, et al., 1976). We report 2 children with virilising CAH of prepubertal age but with advanced pubertal signs in whom LH-RH tests were performed before initiation of therapy.

\section{Subjects and methods}

Case 1. A boy was referred at the age of 9.9 years because of sexual precocity. The parents are distant cousins and new immigrants from the USSR. Another sibling, raised as a boy, at the age of 25 years was found to be suffering from $\mathrm{CAH}$ and genetically to be a female. The patient had full sexual development, appearing to be a mature but short young man, pubertal sign P5 according to Tanner (1962). The clinical data are given in Table 1 .

Case 2. A girl was referred at the age of 9.8 years because of an enlarged clitoris known to be present

Received 3 October 1977

*Established Investigator of the Chief Scientist Bureau, Ministry of Health since birth. The parents are not related and her brother and sister are normally developed. A paternal aunt was reported to be very hirsute, and unmarried. Clinical examination showed a tall girl with pubertal signs corresponding to P2-3 (Tanner, 1962) (Table 1).

In both patients laboratory investigation proved the diagnosis of CAH due to 21-hydroxylase deficiency of the nonsalt-losing type (Table 2). It is notable that in the boy (Case 1) the plasma testosterone was only partially suppressed by dexamethasone, indicating that most of the testosterone was produced by his prematurely developed testicles.

Plasma LH and FSH were measured by radioimmunoassay before and in response to IV administration of $\mathrm{LH}-\mathrm{RH}, 50 \mu \mathrm{g} / \mathrm{m}^{2}$, in a single bolus injection. The results were rated from P1 (prepubertal) to P5 (fully mature) according to the standards obtained by Dickerman et al. (1976) for normal boys and girls. Before referral and investigation neither of the patients had been treated.

Table 1 Clinical data of 2 children with $C A H$

\begin{tabular}{|c|c|c|c|c|c|c|}
\hline \multirow{2}{*}{$\begin{array}{l}\text { Case } \\
\text { no. }\end{array}$} & \multirow{2}{*}{ Sex } & \multirow{2}{*}{$\begin{array}{l}C A \\
\text { (years) }\end{array}$} & \multirow{2}{*}{$\begin{array}{l}B A \\
\text { (years) }\end{array}$} & \multirow{2}{*}{$\begin{array}{l}\text { Height } \\
(\mathrm{cm})\end{array}$} & \multicolumn{2}{|c|}{ Pubertal rating* } \\
\hline & & & & & $G / B$ & $P H$ \\
\hline 1 & Male & 9.9 & 17 & 150 & $\begin{array}{l}5 \\
\text { (TV }\end{array}$ & 5 \\
\hline 2 & Female & $9 \cdot 8$ & 11 & 147 & 2 & 3 \\
\hline
\end{tabular}

$\mathrm{CA}=$ chronological age $; \mathrm{BA}=$ bone age.

*According to Tanner (1962): $\mathbf{G} / \mathbf{B}=$ genital or breast; $\mathbf{P H}=$ pubic hair; $T V=$ testicular volume. 
Table 2 Laboratory findings in 2 children with $C A H$

\begin{tabular}{|c|c|c|c|c|c|c|c|c|c|c|c|c|}
\hline \multirow[t]{3}{*}{ Case no. } & \multicolumn{4}{|l|}{ Urine } & \multicolumn{8}{|c|}{ Plasma } \\
\hline & \multicolumn{2}{|c|}{$\begin{array}{l}17 \text { ketosteroids } \\
(\mathrm{mg} / 24 h)\end{array}$} & \multicolumn{2}{|c|}{$\begin{array}{l}\text { Pregnanetriol } \\
(\mathrm{mg} / 24 h)\end{array}$} & \multicolumn{2}{|c|}{$\begin{array}{l}A C T H \\
(p g / m l)\end{array}$} & \multicolumn{2}{|c|}{$\begin{array}{l}\text { Progesterone } \\
(\mathrm{ng} / \mathrm{ml})\end{array}$} & \multicolumn{2}{|c|}{$\begin{array}{l}\text { Oestradiol } \\
(\mathrm{pg} / \mathrm{ml})\end{array}$} & \multicolumn{2}{|c|}{$\begin{array}{l}\text { Testosterone } \\
(\mathrm{ng} / 100 \mathrm{ml})\end{array}$} \\
\hline & Basal & Dex & Basal & Dex & Basal & Dex & Basal & Dex & Basal & Dex & Basal & Dex \\
\hline $\begin{array}{l}1 \\
2\end{array}$ & $\begin{array}{r}21.7 \\
9.0\end{array}$ & $\begin{array}{l}4.5 \\
2.0\end{array}$ & $\begin{array}{r}30 \cdot 0 \\
7 \cdot 1\end{array}$ & $\begin{array}{l}3.0 \\
0 \cdot 3\end{array}$ & $\begin{array}{l}140 \\
300\end{array}$ & $\begin{array}{l}16 \\
45\end{array}$ & $\begin{array}{r}3 \cdot 7 \\
13 \cdot 5\end{array}$ & $\begin{array}{l}0 \cdot 1 \\
0 \cdot 16\end{array}$ & $\begin{array}{l}25 \\
78\end{array}$ & $\begin{array}{l}19 \\
29\end{array}$ & $\begin{array}{r}350 \\
97\end{array}$ & $\begin{array}{r}230 \\
16\end{array}$ \\
\hline
\end{tabular}

Dex =Dexamethasone suppression, administration of dexamethasone orally, $1 \mathrm{mg}$ (Case 1), $0.5 \mathrm{mg}$ (Case 2), every 6 hours for 3 days.

Conversion: Traditional units to SI-17-ketosteroids: $1 \mathrm{mg} / 24 \mathrm{~h} \approx 3.47 \mu \mathrm{mol} / 24 \mathrm{~h}$. Pregnanetriol: $1 \mathrm{mg} / 24 \mathrm{~h} \approx 2.97 \mu \mathrm{mol} / 24 \mathrm{~h}$. Progesterone:

$1 \mathrm{ng} / \mathrm{ml} \approx 3 \cdot 178 \mathrm{nmol} / 1$. Oestradiol: $1 \mathrm{pg} / \mathrm{ml} \approx 3 \cdot 671 \mathrm{pmol} / 1$. Testosterone: $1 \mathrm{ng} / 100 \mathrm{ml} \approx 34 \cdot 67 \mathrm{nmol} / 1$.

Table 3 Gonadotrophin response to IV $\mathrm{LH}-\mathrm{RH} 50 \mu \mathrm{g} / \mathrm{m}^{2}$ in 2 children with $\mathrm{CAH}$

\begin{tabular}{|c|c|c|c|c|c|c|c|c|c|c|c|c|}
\hline \multirow[t]{3}{*}{$\begin{array}{l}\text { Case } \\
\text { no. }\end{array}$} & \multicolumn{6}{|c|}{ Plasma LH $(m I U / m l)$} & \multicolumn{6}{|c|}{ Plasma FSH $(\mathrm{mlU} / \mathrm{ml})$} \\
\hline & \multicolumn{6}{|c|}{ Minutes } & \multicolumn{6}{|c|}{ Minutes } \\
\hline & 0 & 15 & 30 & 45 & 60 & 90 & 0 & 15 & 30 & 45 & 60 & 90 \\
\hline $\begin{array}{l}1 \\
2\end{array}$ & $\begin{array}{l}1.5 \\
1.2\end{array}$ & $\begin{array}{l}7.5 \\
4 \cdot 7\end{array}$ & $\begin{array}{r}11.8 \\
5.9\end{array}$ & $\begin{array}{r}11.8 \\
4.7\end{array}$ & $\begin{array}{r}14.2 \\
4.6\end{array}$ & $\begin{array}{l}6.4 \\
3.6\end{array}$ & $\begin{array}{l}3 \cdot 8 \\
2 \cdot 1\end{array}$ & $\begin{array}{l}6.9 \\
3.6\end{array}$ & $\begin{array}{l}7.4 \\
4.4\end{array}$ & $\begin{array}{r}12 \cdot 1 \\
4 \cdot 2\end{array}$ & $\begin{array}{r}10.1 \\
5.4\end{array}$ & $\begin{array}{l}6.5 \\
4.4\end{array}$ \\
\hline
\end{tabular}

\section{Results}

The basal plasma LH and FSH levels (Table 3) were higher in our 2 patients than in normal children of the same age: prepubertal male (mean $\pm \mathrm{SD}$ ) LH $0.54 \pm 0 \cdot 1$, FSH $0.6 \pm 0.2$; prepubertal female LH $0.43 \pm 0.12$, FSH $0.6 \pm 0.3$ (Dickerman et al., 1976). The peak response to LH-RH (Table 3) was also greater than that expected in children of prepubertal age, which in our clinic is: male LH $1 \cdot 3 \pm$ $0 \cdot 17$, FSH $1.5 \pm 0.5$; female LH $3.03 \pm 0 \cdot 34$, FSH $2 . - \pm 0.9$ (Dickerman et al., 1976). In the boy (Case 1) the response of LH and FSH corresponded to P5 (full maturity) and in the girl (Case 2) to P3, i.e. corresponding to their clinical pubertal stage and bone age (Table 4) but markedly advanced for their chronological age.

\section{Discussion}

The increased secretion of adrenal androgens which starts in utero in congenital adrenal hyperplasia

Table 4 Correlation between pubertal ratings determined according to the clinical signs and gonadotrophin secretion

\begin{tabular}{|c|c|c|c|c|c|c|}
\hline \multirow[t]{3}{*}{ Case no. } & \multirow{3}{*}{$\begin{array}{l}C A \\
\text { (years) }\end{array}$} & \multirow{3}{*}{$\begin{array}{l}B A \\
\text { (years) }\end{array}$} & \multicolumn{4}{|c|}{ Pubertal rating } \\
\hline & & & \multicolumn{2}{|c|}{ Clinical $^{*}$} & \multicolumn{2}{|c|}{ Laboratory $\dagger$} \\
\hline & & & $G / B$ & $P H$ & $L H$ & $F S H$ \\
\hline $\begin{array}{l}1 \\
2\end{array}$ & $\begin{array}{l}9.9 \\
9.8\end{array}$ & $\begin{array}{l}17 \\
11\end{array}$ & $\begin{array}{l}5 \\
2\end{array}$ & $\begin{array}{l}5 \\
3\end{array}$ & $\begin{array}{l}5 \\
3\end{array}$ & $\begin{array}{l}5 \\
3\end{array}$ \\
\hline
\end{tabular}

*Tanner (1962). †Dickerman et al. (1976).
(CAH) raises some questions as to their possible influence on subsequent development, both clinical and psychological (Laron et al., 1974). How do the sex hormones influence the normal function of the hypothalamo-pituitary-gonadal (H-P-G) axis, and how can the oversecretion of gonadotrophins be related to the basic overproduction of adrenal sex hormones? Reiter et al. (1975) showed that the regulation of the H-P-G axis was preserved ' . . . both in the maturity-related $\mathrm{LH}$ release and in the sex dichotomy of the FSH release evoked by LH-RH'. Other reports, however, provide evidence that in patients with untreated or poorly controlled CAH, gonadotrophin secretion was suppressed (Klingensmith et al., 1976; Wentz et al., 1976) and the H-P-G axis disrupted (Kirkland et al, 1974) by the raised adrenal sex hormones. It has also been reported that in patients treated with suboptimal doses of corticosteroids, treatment with optimal doses which adequately suppressed the abnormally raised sex hormones led to the onset of precocious puberty and menstruation (Penny et al., 1973; Klingensmith et al., 1976).

Our studies in 2 patients of prepubertal age with untreated CAH show that the levels of both basal and readily-releasable pituitary LH and FSH are raised for their chronological age, corresponding to the respective stage of sexual precocity and advanced bone age. These findings are similar to those reported by Stevens and Goldzieher (1968), who measured urinary gonadotrophins, and in contrast to the usual finding of delayed normal pubertal process found in children with CAH (Klingensmith et al., 1976). 
The relative hypersecretion of gonadotrophins in untreated $\mathrm{CAH}$ could be explained either by an overlap mechanism induced by the hypersecretion of ACTH, similar to that encountered in primary hypothyroidism and precocious puberty (Laron et al., 1970), or by a direct effect of the sex hormones on the hypothalamus or pituitary. Reiter et al. (1975) raised the possibility that chronologically raised levels of adrenal sex hormones induce precocious maturation of the hypothalamus by lowering its sensitivity to the negative feedback of the sex steroids. This suggestion is reinforced by the acceleration of central precocious puberty observed after initiation of corticosteroid therapy in young children with CAH and advanced bone age (Penny et al., 1973; Reiter et al., 1975).

We thank the late Dr J. Mulder of Ferring AB, Malmo, Sweden, for the supply of LH-RH.

\section{References}

Dickerman, Z., Prager-Lewin, R., and Laron, Z. (1976). The response of plasma LH and FSH to synthetic LH-RH in normal boys and girls at various pubertal stages. American Journal of Diseases of Children, 130, 634-638.

Kirkland, J., Kirkland, R., Librik, L., and Clayton, G. (1974). Serum gonadotropin levels in female adolescents with congenital adrenal hyperplasia. Journal of Pediatrics, 84, 411-414.

Klingensmith, G. J., Wentz, A. C., Meyer, W. J., and Migeon C. J. (1976). Gonadotropin output in congenital adrenal hyperplasia before and after adrenal suppression. Journal of Clinical Endocrinology and Metabolism, 43, 933-936.

Laron, Z., Karp, M., and Dolberg, L. (1970). Juvenile hypothyroidism with testicular enlargement. Acta Paediatrica Scandinavica, 59, 317-322.

Laron, Z., Pertzelan, A., Shurka, E., Galatzer, A., Gil, R., and Frisch, M. (1974). Physiological and psychological aspects of puberty of patients with congenital adrenocortical virilism (CAV). Sexual Endocrinology of the Perinatal Period, pp. 407-420. Ed. by M. G. Forest and J. Bertrand. INSERM, Paris.

Penny, R., Olambiwonnu, N. O., and Frasier, S. D. (1973). Precocious puberty following treatment in a six-year-old male with congenital adrenal hyperplasia: studies of serum luteinizing hormone $(\mathrm{LH})$, serum follicular stimulating hormone (FSH) and plasma testosterone. Journal of Clinical Endocrinology and Metabolism, 36, 920-924.

Reiter, E. O., Grumbach, M. M., Kaplan, S. L., and Conte, F. A. (1975). The response of pituitary gonadotropes to synthetic LRF in children with glucocorticoid-treated congenital adrenal hyperplasia: lack of effect of intrauterine and neonatal androgen excess. Journal of Clinical Endocrinology and Metabolism, 40, 318-325.

Stevens, V. C., and Goldzieher, J. W. (1968). Urinary excretion of gonadotropins in congenital adrenal hyperplasia. Pediatrics, 41, 421-427.

Tanner, J. M. (1962). Growth at Adolescence, 2nd ed.. p. 152. Blackwell, Oxford.

Wentz, A. C., Garcia, S. C., Klingensmith, G. J., Migeon, C. J., and Jones, G. S. (1976). Gonadotropin output and response to LRH administration in congenital virilizing adrenal hyperplasia. Journal of Clinical Endocrinology and Metabolism, 42, 239-246.

Correspondence to Professor Z. Laron, Institute of Paediatric and Adolescent Endocrinology, Beilinson Medical Centre, Petah Tikva, Israel. 